\title{
Carbapenem resistant Escherichia coli and Pseudomonas aeruginosa in captive blackbucks (Antilope cervicapra) and leopards (Panthera pardus) from India
}

\author{
Obli R. Vinodh Kumar ${ }^{1 *}$, Bhoj R. Singh ${ }^{1}$, Mathesh Karikalan², Shikha Tamta ${ }^{1}$, \\ Jai K. Jadia ${ }^{3}$, Dharmendra K. Sinha ${ }^{1}$, Karunanidhi Mahendran ${ }^{4}$, Ramkumar N. Rupner$^{1}$, \\ Ravichandran Karthikeyan', and Anil K. Sharma² \\ ${ }^{1}$ Division of Epidemiology, ICAR-Indian Veterinary Research Institute, Bareilly, India \\ ${ }^{2}$ Centre for Wildlife, ICAR-Indian Veterinary Research Institute, Bareilly, India \\ ${ }^{3}$ Veterinary Officer, Nandanvan Zoo, Raipur, Chhattisgarh, India \\ ${ }^{4}$ Division of Medicine, ICAR-Indian Veterinary Research Institute, Bareilly, India
}

VINODH KUMAR, O. R, B. R. SINGH, M. KARIKALAN, S. TAMTA, J. K. JADIA, D. K. SINHA, K. MAHENDRAN, R. N. RUPNER, R. KARTHIKEYAN, A. K. SHARMA: Carbapenem resistant Escherichia coli and Pseudomonas aeruginosa in captive blackbucks (Antilope cervicapra) and leopards (Panthera pardus) from India. Vet. arhiv 91, 73-80, 2021.

\section{ABSTRACT}

The study aimed to investigate the occurrence of carbapenem resistant E. coli and $P$. aeruginosa in apparently healthy, captive blackbucks and leopards of India. Faecal samples of blackbucks $(\mathrm{n}=7)$ and leopards $(\mathrm{n}=7)$ were processed to isolate carbapenem resistant $E$. coli $(\mathrm{CRE})$ and $P$. aeruginosa $(\mathrm{CRP})$. Forty (leopards $\mathrm{n}=26$; blackbuck $\mathrm{n}$ $=14)$ E. coli and two $P$. aeruginosa (blackbuck $n=2$ ) samples were isolated from the faecal samples $(\mathrm{n}=14)$. Eleven carbapenem resistant isolates were recovered, of which 10 were CRE and one was CRP. The minimum inhibitory concentration (MIC) was determined for meropenem for carbapenem resistant isolates and was between 8 and 64 $\mu \mathrm{g} / \mathrm{mL}$. All the CRE and CRP were phenotypically multidrug resistant, and six CRE were extended-spectrum betalactamases (ESBL) producers. On genotypic screening, seven CRE and one CRP were positive for the blaNDM carbapenemase gene. Efflux pump-mediated carbapenem resistance was noticed in four CRE isolates (36.4\%, 4/11). Of the six ESBL producing CRE, four isolates carried blaCTX-M-1 genes. The CRE isolates also harbored blaTEM-1, blaAmpC, qnrA, qnrB, qnrS, tetA, tetB and sul1 resistance genes. On Shiga toxin virulence screening, Stx 1 , Stx 2 genes were detected in two and one isolates, respectively. Plasmid typing of CRE revealed that the blaNDM genes were carried on an Incl1 plasmid. The plasmid multilocus sequence typing (pMLST) of the isolates showed the Sequence Type (ST) 297. The occurrence of carbapenem resistance bacteria in captive wildlife should be a major public health priority.

Key words: ESBL; E. coli; Shiga toxin; wildlife; Carbapenem-resistance; NDM

\footnotetext{
*Corresponding author:

Obli Rajendran Vinodh Kumar, Division of Epidemiology, ICAR- Indian Veterinary Research Institute, Bareilly, India, Phone: + 9188 5978 4853 ; E-mail: vinodhkumar.rajendran@gmail.com
} 


\section{Introduction}

Antimicrobial resistance is an emerging global threat and needs immediate attention. It is a complex and multidimensional problem involving humans, animals, and the environment. The intensive and indiscriminate use of antimicrobials in humans and animals has resulted in the emergence of antimicrobial resistance (AMR) in humans, animals, and the environment (BERENDONK et al., 2015). Transmission of carbapenem resistant Enterobacteriales between animals and exposed humans has been reported (KOCK et al., 2018).

Carbapenems are one of the most important groups of antimicrobials, and are considered as the last line of drugs for the treatment of severe infections. Carbapenem resistance in animals appears to have developed and disseminated as a consequence of clinical carbapenem use in human medicine (MURUGAN et al., 2019). The present study was planned to investigate the occurrence and to characterize carbapenem resistant $E$. coli and $P$. aeruginosa in captive blackbucks and leopards of India.

\section{Materials and methods}

Sample collection. A cross-sectional study was conducted during 2015-16 in a zoo for screening antibacterial resistance in apparently healthy captive blackbucks and leopards. The representative faecal samples from blackbucks $(n=7)$ and leopards $(n=$ 7) were collected in sterile transport swabs.

Isolation and identification of E. coli and P. aeruginosa. Each faecal swab was pre-enriched in buffered peptone water (incubation at $37{ }^{\circ} \mathrm{C}$ for $2-4 \mathrm{~h}) 37{ }^{\circ} \mathrm{C}$, the inoculums were streaked on Hektoen enteric agar (HEA) plates, and on HEA yellow colour colonies were considered to be presumptive $E$. coli, while the transparent non-fermenting colonies were considered to be presumptive Pseudomonas. From each plate, 3-4 presumptive E. coli and Pseudomonas colonies were taken out and the respective colonies were streaked on MacConkey agar plates with imipenem $(0.5 \mathrm{mg} / \mathrm{L})$ added, and incubated at $37^{\circ} \mathrm{C}$ overnight (PRUTHVISHREE et al., 2017). Subsequently, the characteristic isolated colonies were extracted for identification by biochemical tests.
Antibacterial screening of $E$. coli and $P$. aeurogenosa isolates. Reference strains ( GenBank accession number KT853018, KT867018, KT867020 and KT867021) obtained from the Division of Epidemiology, Indian Veterinary Research Institute, Izatnagar repository, were used in this study as positive controls. The recovered E. coli $(\mathrm{n}=40)$ and P. aeruginosa $(\mathrm{n}=2)$ isolates were tested for antibacterial susceptibility patterns against meropenem (MEM, $10 \mu \mathrm{g}$ ), imipenem (IMP, $10 \mu \mathrm{g})$ and ertapenem (ETP, $10 \mu \mathrm{g})$ disks (BD, Sparks, MD, USA) along with metal ion chelator ethylene diamine tetra acetic acid (EDTA; 1900 $\mathrm{mg}$ ), to screen for metallo beta-lactamase (MBL) production (PRUTHVISHREE et al., 2017). A keyhole reaction between the carbapenem drug and EDTA was considered positive for MBL.

For phenotypic identification of ESBL producers, the combination disc method was used (ANDREWS, 2003) by cefotaxime and ceftazidime, with and without clavulanic acid. Once the zone of inhibition between the combination disc and the corresponding single antibacterial disc differed by $\geq 5 \mathrm{~mm}$, the isolate was identified as an ESBL producer. The isolates were further confirmed as ESBL producers using the E-test. The isolates were also screened for aztreonam (ATZ, $30 \mu \mathrm{g}$ ), chloramphenicol (C, $30 \mu \mathrm{g})$, ceftriaxone (CTR, $30 \mu \mathrm{g})$, cefpodoxime (CPD, $10 \mu \mathrm{g})$, ceftazidime (CAZ, $30 \mu \mathrm{g}$ ), cefotaxime (CTX, $30 \mu \mathrm{g}$ ), cefepime (CPM, $30 \mu \mathrm{g}$ ), cefixime (CFM, $5 \mu \mathrm{g}$ ), cefoxitin (FOX, $30 \mu \mathrm{g}$ ), piperacillin - tazobactam (TZP, $100 / 10 \mu \mathrm{g})$, cefotaxime/clavulanic acid $(30 / 10 \mu \mathrm{g})$, tetracycline (TE, $30 \mu \mathrm{g}$ ), nitrofurantoin (F/M, 300 $\mu \mathrm{g}$ ), gentamicin (GEN, $10 \mu \mathrm{g}$ ), co-trimoxazole (COT, $25 \mu \mathrm{g}$ ), ciprofloxacin (CIP, $5 \mu \mathrm{g}$ ) and norfloxacin (NX,10 $\mu \mathrm{g}$ ) by the disc diffusion method. The CLSI, 2014 breakpoints were used for interpretation of the susceptibility pattern. The MIC against meropenem, ceftriaxone, cefotaxime was determined using E-test strips (HiMedia, Mumbai, India) for the carbapenem resistant isolates $(\mathrm{n}=11)$.

PCR for carbapenemase producing genes and sequencing. PCR was carried out targeting betalactamase (PRUTHVISHREE et al., 2017), major 
carbapenemase (POIREL et al., 2011), Shiga toxin virulence markers (PATON and PATON, 1998), sulphonamide resistance (KERRN et al., 2002), and plasmid mediated quinolone resistance (PMQR) determinants (CIESIELCZUK et al., 2013) and tetracycline resistance (MAYNARD et al., 2004) genes. The reactions were optimized individually in $25 \mu \mathrm{L}$ volumes with 10 picomoles of each primer. The PCR amplicon from all reactions was electrophoresed in $0.5 \mathrm{X}$ TBE buffer using $1.5 \%$ agarose gel, and visualized under UV illumination (Syngene, USA). The PCR amplicons (blaNDM and blaAmpC) were purified and sequenced by commercial sequencing services (Eurofins, Bengaluru, India). The sequencing results were obtained and homology searches were performed using the BLAST algorithm (http://blast.ncbi. nlm.nih.gov/Blast.cgi). The sequence data were submitted to GenBank, and the accession numbers were obtained.

Plasmid replicon and multilocus sequence (MLST) typing of E. coli isolates. The plasmid DNA was extracted from E. coli by a Qiagen Miniprep kit (Qiagen, India) from the blaNDM positive $E$. coli. Plasmids were assigned to incompatibility groups by multiplex PCR (JOHNSON et al., 2007). After assigning the incompatibility groups, the corresponding plasmid MLST was performed using specific primers (GARCIA-FERNANDEZ et al., 2018) and sequenced by the Sanger method (Eurofins India Ltd, Bengaluru). The sequences were edited using BioEdit v7.0.5 and examined on the plasmid MLST website (https://pubmlst. org/bigsdb?db $=$ pubmlst plasmid seqdef) for the allelic profile, sequence type, and clonal complex.

Assay for overexpressed efflux pumps. Isolates not showing carbapenemase mediated resistance were screened for the presence of an active efflux pump by the ethidium bromide agar cartwheel method (PRUTHVISHREE et al.,2017).

\section{Results and discussion}

From the faecal samples, forty (leopards $\mathrm{n}=26$; blackbucks $\mathrm{n}=14)$ E. coli and two P. aeruginosa (blackbucks $\mathrm{n}=2$ ) were isolated. From each animal swab, 3-4 presumptive E. coli and Pseudomonas colonies were picked up and characterized. The $E$. coli isolates from leopards $(\mathrm{n}=26)$ and blackbucks $(\mathrm{n}=14)$ screened for carbapenem resistance revealed that nine $E$. coli from leopards and one $E$. coli from blackbucks were carbapenem resistant. Pseudomonas aeruginosa could only be isolated from blackbuck faecal samples. The CRE $(\mathrm{n}=9)$ from leopards were resistant to MEM $(9 / 9,100 \%)$ followed by IMP $(8 / 9,88.9 \%)$ and ETP $(6 / 9$, 66.7\%). Similarly the CRE $(n=1)$ and CRP $(n=1)$ from blackbucks were resistant to MRP.

In addition, the CRP $(\mathrm{n}=1)$ was also resistant to IMP and ETP. The reason for the higher MEM resistance might be associated with the increased clinical use of meropenem in India (GANDRA et al., 2016). Of the carbapenem resistant isolates $(\mathrm{n}=$ 11), seven CRE ( $n=6$ from leopards and $n=1$ from blackbucks) and one CRP from blackbucks showed the keyhole reaction with EDTA, indicating metallo beta-lactamase (MBL) production. The minimum inhibitory concentration (MIC) for meropenem of the carbapenem resistant isolates ranged from 8 to $64 \mu \mathrm{g} / \mathrm{mL}$ (Table 1). All the carbapenem resistant isolates $(\mathrm{n}=11)$ were phenotypically multidrug resistant (i.e. strains showing resistance to at least two groups of antibacterials), and six were ESBL producers. Extended spectrum beta-lactamase and carbapenemase producing Gram-negative bacteria have been reported in neonates of India (DEVI et al., 2018). The increase in infections associated with multi-drug resistant and ESBL producing pathogens demands the use of carbapenems. This might have led to the emergence of carbapenem resistance among organisms, and causes a challenge for treatment (GANDRA et al., 2016).

The antibiogram of the CRE $(n=10)$ and CRP $(n$ $=1$ ) showed that the isolates were $100 \%$ resistant to ATZ, CTR, CAZ, CTX, CPD, CFM, and GEN. The isolates were also resistant to TE $(9 / 11,81.8 \%)$, CIP (9/11, 81.8\%), COT (7/11,63.6\%), C (5/11,45.5\%), F/M (5/11, 45.5\%) and TZP (5/11, 45.5\%) (Table 1). Resistance to sulfonamides, aminoglycosides, trimethoprim, tetracycline, and fluoroquinolones was detected in migratory avian species in Pakistan (MOHSIN et al., 2017). 
O. R. Vinodh Kumar et al.: Carbapenem resistant E. coli and Pseudomonas aeruginosa in captive blackbucks and leopards

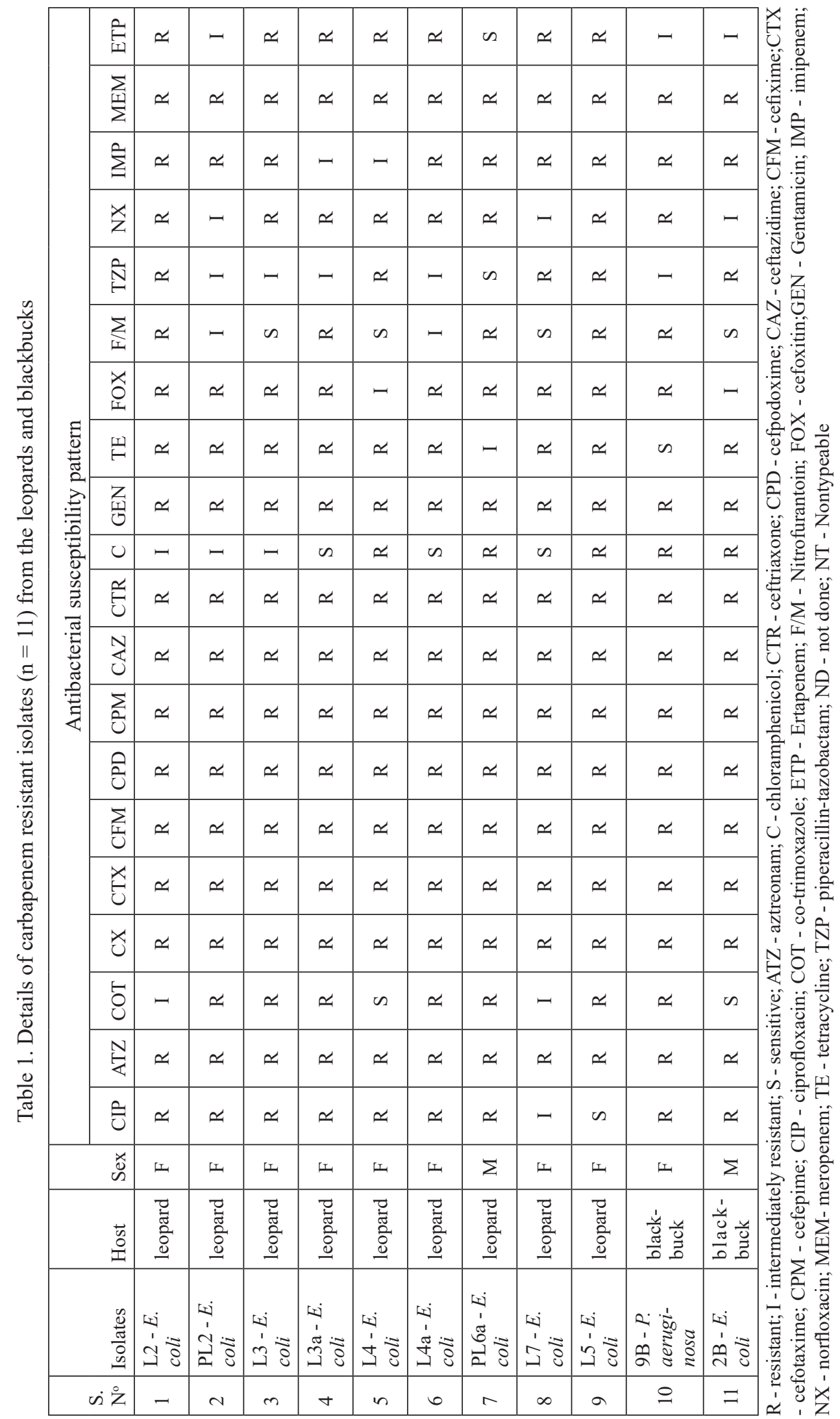


O. R. Vinodh Kumar et al.: Carbapenem resistant E. coli and P. aeruginosa in captive blackbucks and leopards

Table 1. Details of carbapenem resistant isolates $(\mathrm{n}=11)$ from the leopards and blackbucks (continued)

\begin{tabular}{|c|c|c|c|c|c|c|c|c|}
\hline \multirow{2}{*}{$\begin{array}{l}\mathrm{S} . \\
\mathrm{N}^{\circ}\end{array}$} & \multicolumn{3}{|c|}{$\begin{array}{l}\text { Minimum inhibitory } \\
\text { concentration }(\mu \mathrm{g} / \mathrm{mL})\end{array}$} & \multirow{2}{*}{$\begin{array}{l}\text { Efflux } \\
\text { pump }\end{array}$} & \multirow{2}{*}{$\begin{array}{l}\text { Virulence and antibacterial } \\
\text { resistance determinants }\end{array}$} & \multirow{2}{*}{$\begin{array}{c}\text { Accession } \\
\text { number }\end{array}$} & \multirow{2}{*}{$\begin{array}{c}\text { Plasmid } \\
\text { type }\end{array}$} & \multirow{2}{*}{$\begin{array}{c}\text { Sequence } \\
\text { type }\end{array}$} \\
\hline & CTX & CTR & MRP & & & & & \\
\hline 1 & 8 & 16 & 16 & Active & blaNDM-7, tetA, qnrS & KU318701 & Inc1 & ST-297 \\
\hline 2 & 16 & 32 & 32 & Not- active & $\begin{array}{l}\text { blaNDM-7, blaCTX-M-1, sul1, } \\
\text { tetA, qnrS, stx2 }\end{array}$ & KU318696 & Inc 1 & ST-297 \\
\hline 3 & 16 & 8 & 8 & Not- active & $\begin{array}{c}\text { blaNDM-5, blaAmpC, } \\
\text { blaCTX-M-1, tetA, stx2 }\end{array}$ & $\begin{array}{l}\text { KU318691, } \\
\text { KU382501 }\end{array}$ & Inc1 & ST-297 \\
\hline 4 & 8 & 32 & 16 & Not-active & blaNDM-5, blaTEM-1, sul1, qnrA & KU318700 & Inc1 & ST-297 \\
\hline 5 & 16 & 16 & 32 & Not- active & blaNDM-5, sul1, tetA, qnrS & KU318698 & Inc1 & ST-297 \\
\hline 6 & 16 & 32 & 64 & Not- active & blaNDM-7, sul1, tetB, qnrB & KU318702 & Inc1 & ST-297 \\
\hline 7 & 8 & 8 & 16 & Not- active & blaNDM-5, sul1, tetA, sxt1 & KU318699 & NT & NT \\
\hline 8 & 32 & 32 & 16 & Active & blaCTX-M-1, tetB, sul1 & - & ND & ND \\
\hline 9 & 16 & 16 & 8 & Active & blaCTX-M-1, sul1 & - & ND & ND \\
\hline 10 & 32 & 64 & 8 & Not- active & blaNDM-1, blaAmpc, blaTEM-1 & $\begin{array}{l}\text { KU523520, } \\
\text { KU382500 } \\
\end{array}$ & ND & ND \\
\hline 11 & 16 & 16 & 16 & Active & tetA, qnrS & - & NT & NT \\
\hline
\end{tabular}

R - resistant; I - intermediately resistant; S - sensitive; ATZ - aztreonam; C - chloramphenicol; CTR - ceftriaxone; CPD - cefpodoxime; CAZ - ceftazidime; CFM - cefixime; CTX - cefotaxime; CPM - cefepime; CIP - ciprofloxacin; COT - co-trimoxazole; ETP Ertapenem; F/M - Nitrofurantoin; FOX - cefoxitin; GEN - Gentamicin; IMP - imipenem; NX - norfloxacin; MEM- meropenem; TE - tetracycline; TZP - piperacillin-tazobactam; ND - not done; NT - Nontypeable

The genotypic screening, targeting five major carbapenemase genes, showed that seven CRE and one CRP (blackbuck, 9B) isolates were positive for the blaNDM carbapenemase gene. Of the eight NDM positives, four CRE isolated from leopards were NDM-5, three CRE from leopards were NDM7, and one CRE from a blackbuck was a NDM-1 variant. The blaNDM and blaAmpC gene sequences were submitted to GenBank, and the accession numbers were obtained (Table 1). Carbapenemase producing $P$. aeruginosa was reported in livestock animals in Lebanon (Al BAYSSARI et al., 2014). Carbapenem resistant blaNDM positive $E$. coli were detected in food animals and pet animals in India (PRUTHVISHREE et al.,2017; PRUTHVISHREE et al., 2018; MURUGAN et al.,2019) and wild black kites (FISCHER et al., 2013). Efflux pump mediated carbapenem resistance was noticed in three leopard and one blackbuck CRE isolates (L2, L5, L7, 2B). One CRE (L2) isolate of a leopard harboured both blaNDM -7 genes and an active efflux pump. Earlier, efflux pump mediated carbapenem resistance was observed in E. coli isolated from piglets (PRUTHVISHREE et al., 2017). The carbapenem resistance of the isolates $(\mathrm{n}=11 ; \mathrm{CRE}=10 ; \mathrm{CRP}=1)$ was either by means of carbapenem genes or active efflux pumps.

All the carbapenem resistant and MBL positive isolates $(\mathrm{n}=8)$ carried blaNDM genes. In the ESBL genotypic screening $(\mathrm{n}=6)$, four isolates carried blaCTX-M-1 genes. In addition, blaTEM-1, blaAmpC,qnrA, qnrB, qnrS,tet $\mathrm{A}$, tet $\mathrm{B}$ and sul1 resistance genes were detected in CRE isolates. Carbapenem and extended spectrum beta-lactam co-resistance in $E$. coli have been reported in critical care human patients (JOHNSON et al., 2017) and blaCTX-M-1 has been reported in E. coli isolated from healthy animals and humans (BEN SALLEM et al., 2014). On Shiga toxin virulence screening, St $x$, Stx 2 genes were detected in two and one isolates, respectively. E. coli isolates carrying both carbapenem resistance and virulence factors have been reported in humans, dogs and food animals (CANDAN and AKSOZ, 2017; PRUTHVISHREE et al., 2018; MURUGAN et al., 2019; VINODH KUMAR et al., 2019; TAMTA et al., 2020). Shiga 
toxigenic markers were detected in $16.0 \%$ of the ESBL producing $E$. coli of piglets (NIRUPAMA et al., 2018). The presence of virulence markers and carbapenem resistance genes in E. coli isolates from captive wildlife is of critical importance. Plasmid replicon typing of CRE revealed that the blaNDM5 and blaNDM7 genes were harboured on Incll plasmids. The plasmid multilocus sequence typing (pMLST) of the blaNDM isolates displayed ST 297, which was also reported in the ESBL producing $E$. coli isolated from wild birds (YAHIA et al., 2018). Interestingly, the CRE from leopards harboured Incl1 plasmids carrying NDM genes and also a similar sequence type (ST- 297), indicating the transmission of resistance. Incll type plasmids were reported in ESBL producing E. coli from migratory avian species in Pakistan (MOHSIN et al., 2017), and most of the ESBL genes were carried on Incl1 plasmids (GARCIA-FERNANDEZ et al., 2008).

\section{Conclusion}

This is a prima facie report on carbapenem resistance in E. coli and pseudomonas in captive wildlife. Despite the small sample size, the study highlighted the emergence of carbapenem resistance in E. coli and P.aeurginosa isolated from apparently healthy leopards and blackbucks. The occurrence and spread of carbapenem resistance bacteria in captive wildlife should be a major public health priority. Thus, surveillance and appropriate measures for the control of their spread are extremely important.

\section{Conflict of interest}

There is no conflict of interest among the authors.

\section{Funding and Ethical Approval}

The authors thank the Director, IVRI, for providing the necessary funds to carry out the research work. The research meets all applicable standards with regard to the ethics of experimentation and research integrity, and the following is certified/declared to be true.

\section{Acknowledgment}

The authors thank the Director, IVRI, Ministry of Environment, Forest and Climate Change, Central zoo authority, Government of India, and Nandanvan zoo authorities, Raipur for providing the facilities to carry out the research work.

\section{References}

AL BAYSSARI, C., F. DABBOUSSI, M. HAMZE, J.M. ROLAIN (2014): Emergence of carbapenemase producing Pseudomonas aeruginosa and Acinetobacter baumannii in livestock animals in Lebanon. J. Antimicrob. Chemother. 70, 950-951.

DOI: $10.1093 / \mathrm{jac} / \mathrm{dku} 469$

ANDREWS, J. (2003): Detection of extended-spectrum betalactamases (ESBLs) in E. coli and Klebsiella species. British society for antimicrobial chemotherapy.

BEN SALLEM, R., K. B. SLAMA, B. ROJO-BEZARES, N. PORRES-OSANTE, A.JOUINI, N. KLIBI, A. BOUDABOUS, Y.SAENZ, C.TORRES (2014): IncI1 plasmids carrying bla CTX-M-1 or bla CMY-2 genes in Escherichia coli from healthy humans and animals in Tunisia. Microb. Drug. Resist. 20, 495-500.

DOI: $10.1089 / \mathrm{mdr} .2013 .0224$

BERENDONK, T. U., C. M. MANAIA, C. MERLIN, D. FATTA-KASSINOS, E. CYTRYN, F. WALSH, H. BURGMANN, H. SORUM, M. NORSTROM, M.N. PONS, N. KREUZINGER (2015): Tackling antibiotic resistance: the environmental framework. Nat. Rev. Microbiol. 13, 310.

DOI: $10.1038 /$ nrmicro3439

CANDAN, E. D., N. AKSOZ (2017): Escherichia coli: Characteristics of carbapenem resistance and virulence factors. Braz. Arch. Biotechno. 60, e17160410.

DOI: $10.1590 / 1678-4324-2017160416$

CIESIELCZUK, H., M. HORNSEY, V. CHOI, N. WOODFORD, D. W. WAREHAM (2013): Development and evaluation of a multiplex PCR for eight plasmid mediated quinolone resistance determinants. J. Med. Microbiol. 62, 1823-1827.

DOI: 10.1099/jmm.0.064428-0

DEVI, U., R. BORA, J. K. DAS, J. MAHANTA (2018): Extended spectrum $\beta$-lactamase \& carbapenemaseproducing Gram-negative bacilli in neonates from a tertiary care centre in Dibrugarh, Assam, India. Indian. J. Med. Res. 147, 110.

DOI: $10.4103 /$ ijmr.ijmr_1288_16

FISCHER, J., S. SCHMOGER, S. JAHN, R. HELMUTH, B. GUERRA (2013): NDM-1 carbapenemase-producing Salmonella enterica subsp. Enterica serovar Corvallis isolated from a wild bird in Germany. J. Antimicrob. Chemother. 68,2954-6.

DOI: $10.1093 / \mathrm{jac} / \mathrm{dkt} 260$

GANDRA, S., E. Y. KLEIN, S. PANT, S. MALHOTRAKUMAR, R. LAXMINARAYAN (2016): Faropenem consumption is increasing in India. Clin. Infect. Dis. 62, 1050-2.

DOI: $10.1093 / \mathrm{cid} / \mathrm{ciw} 055$

GARCIA-FERNANDEZ, A., G. CHIARETTO, A. BERTINI, L. VILLA, D. FORTINI, A. RICCI, A. CARATTOLI (2008): Multilocus sequence typing of IncI1 plasmids 
O. R. Vinodh Kumar et al.: Carbapenem resistant $E$. coli and P. aeruginosa in captive blackbucks and leopards

carrying extended-spectrum $\beta$-lactamases in Escherichia coli and Salmonella of human and animal origin. J. Antimicrob. Chemother. 61, 1229-33.

DOI: $10.1093 / \mathrm{jac} / \mathrm{dkn} 131$

JOHNSON, J. K., G. L. ROBINSON, L. L. PINELES, A. O. AJAO, L. ZHAO, J. S. ALBRECHT, A. D. HARRIS, K. A. THOM, J. P. FURUNO (2017): Carbapenem MICs in Escherichia coli and Klebsiella species producing Extended spectrum $\beta$-Lactamases in Critical Care Patients from 2001 to 2009. Antimicrob. Agents. Chemother. 61, e01718-16.

DOI: $10.1128 /$ aac.01718-16

JOHNSON, T. J., Y. M. WANNEMUEHLER, S. J. JOHNSON, C. M. LOGUE, D. G. White, C. DOETKOTT, L. K. NOLAN (2007): Plasmid replicon typing of commensal and pathogenic E. coli isolates. Appl. Environ. Microbiol. 73, 1976-1983.

DOI: $10.1128 /$ aem.02171-06

KERRN, M. B., T. KLEMMENSEN, N. FRIMODTMOLLER, F. ESPERSEN (2002): Susceptibility of Danish E. coli strains isolated from urinary tract infections and bacteraemia, and distribution of sul genes conferring sulphonamide resistance. J. Antimicrob. Chemother. 50, 513-516.

DOI: $10.1093 / \mathrm{jac} / \mathrm{dkf1} 64$

KOCK. R., I. DANIELS-HAARDT, K. BECKER, A. MELLMANN, A. W. FRIEDRICH, D. MEVIUS, S. SCHWARZ, A. JURKE (2018): Carbapenem-resistant Enterobacteriaceae in wildlife, food-producing, and companion animals: a systematic review. Clinical. Microbiol. Infect. 24, 1241-1250.

DOI: $10.1016 /$ j.cmi.2018.04.004

MAYNARD, C., S. BEKAL, F. SANSCHAGRIN, R. C. LEVESQUE, R. BROUSSEAU, Masson L, S. LARIVIERE, J. HAREL (2004): Heterogeneity among virulence and antimicrobial resistance gene profiles of extra intestinal $E$. coli isolates of animal and human origin. J. Clin. Microbiol. 42, 5444-5452.

DOI: $10.1128 / \mathrm{jcm} .42 .12 .5444-5452.2004$

MOHSIN, M., S. RAZA, K. SCHAUFLER, N. ROSCHANSKI, F. SARWAR, T. SEMMLER, P. SCHIERACK, S. GUENTHER (2017): High prevalence of CTX-M-15-Type ESBL-producing E. coli from migratory avian species in Pakistan. Front. Microbiol. 8, 2476.

DOI: $10.3389 /$ fmicb.2017.02476

MURUGAN, S. M., D. K. SINHA, O. R. VINODH KUMAR, A. K. YADAV, B. S. PRUTHVISHREE, P. VADHANA, K. R. NIRUPAMA, M. BHARDWAJ, B. R. SINGH (2019): Epidemiology of carbapenem-resistant Escherichia coli and first report of blaVIM carbapenemases gene in calves from India. Epidemiol. Infect. 147, e159.

DOI: $10.1017 / \mathrm{s} 0950268819000463$

NIRUPAMA, K. R., O. R. VINODH KUMAR, B. S. PRUTHVISHREE, D. K. SINHA, M. S. MURUGAN, N. KRISHNASWAMY, B. R. SINGH (2018): Molecular characterization of blaOXA-48 carbapenemase-, extendedspectrum $\beta$-lactamase-and Shiga toxin-producing Escherichia coli isolated from farm piglets in India. J. Glob. Antimicrob. Resist. 13, 201-205.

DOI: 10.1016/j.jgar.2018.01.007

PATON, A.W., J. C. PATON (1998): Detection and characterization of Shiga toxigenic Escherichia coli by using multiplex PCR Assays for stx1, stx 2, eaeA, Enterohemorrhagic E. coli hlyA, rfb O111, and rfb O157. J. Clin. Microbiol. 36, 598-602.

DOI: $10.1128 /$ jcm.36.2.598-602.1998

POIREL, L., T. R. WALSH, V. CUVILLIER, P. NORDMANN (2011): Multiplex PCR for detection of acquired carbapenemase genes. Diagn. Microbiol. Infect. Dis. 70, 119-123.

DOI: 10.1016/j.diagmicrobio.2010.12.002

PRUTHVISHREE, B. S., O. R. VINODH KUMAR, D. K. SINHA, Y. P. MALIK, Z. B. DUBAL, P. A. DESINGU, M. SHIVAKUMAR, N. KRISHNASWAMY, B. R. SINGH (2017): Spatial molecular epidemiology of carbapenemresistant and New Delhi metallo beta-lactamase (blaNDM)producing Escherichia coli in the piglets of organized farms in India. J. Appl. Microbiol. 122, 1537-1546.

DOI: 10.1111 jam. 13455

PRUTHVISHREE, B. S., O. R. VINODH KUMAR, M. SIVAKUMAR, S. TAMTA, R. SUNITHA, D. K. SINHA, B. R, SINGH (2018): Molecular characterization of extensively drug resistant (XDR), extended spectrum beta-lactamases (ESBL) and New Delhi Metallo betalactamase-1 (blaNDM1) producing Escherichia coli isolated from a male dog - a case report. Vet. arhiv 88, 139-148. DOI: $10.24099 /$ vet.arhiv.160924

TAMTA, S., O. R.VINODH KUMAR, B. S. PRUTHVISHREE, R. KARTHIKEYAN, R. N. RUPNER, G. E. CHETHAN, Z. B. DUBAL, D. K.SINHA, B. R. SINGH (2020):Faecal carriage of extended spectrum beta-lactamase (ESBL) and New Delhi metallo beta-lactamase (NDM) producing Escherichia coli between piglets and pig farmworkers. Comp. Immunol. Microbiol. Infect. Dis. 73, 101564.

VINODH KUMAR, O. R., B. R. SINGH, D. K. SINHA, B. S. PRUTHVISHREE, S. TAMTA, Z. B. DUBAL, R. KARTHIKEYAN, R. N. RUPNER, Y. S. MALIK (2019): Risk factor analysis, antimicrobial resistance and pathotyping of Escherichia coli associated with pre-and post-weaning piglet diarrhoea in organised farms. India. Epidemiol. Infect. 147, e174.

DOI: $10.1017 / \mathrm{s} 0950268819000591$

YAHIA, H. B., R. B. SALLEM, G. TAYH, N. KLIBI, I. B. AMOR, H. GHARSA, A. BOUDABBOUS, K. B. SLAMA (2018): Detection of CTX-M-15 harboring Escherichia coli isolated from wild birds in Tunisia. BMC. Microbiol $18,26$.

DOI: $10.1186 / \mathrm{s} 12866-018-1163-2$ 
O. R. Vinodh Kumar et al.: Carbapenem resistant E. coli and Pseudomonas aeruginosa in captive blackbucks and leopards

Received: 1 October 2019

Accepted: 27 October 2020

VINODH KUMAR, O. R, B. R. SINGH, M. KARIKALAN, S. TAMTA, J. K. JADIA, D. K. SINHA, K. MAHENDRAN, R. N. RUPNER, R. KARTHIKEYAN, A. K. SHARMA:Otpornost bakterija Escherichia coli i Pseudomonas aeruginosa na karbapenem u antilope (Antilope cervicapra) i leoparda (Panthera pardus) iz zatočeništva u Indiji. Vet. arhiv 91, 73-80, 2021.

\section{SAŽETAK}

Cilj rada bio je istražiti slučajeve otpornosti bakterija E. coli i P. aeruginosa na karbapenem u zdravih antilopa i leoparda iz zatočeništva u Indiji. Uzorci izmeta antilopa $(n=7)$ i leoparda $(n=7)$ obrađeni su kako bi se izolirale bakterije E. coli (CRE) i P. aeruginosa (CRP) otporne na karbapenem. Iz uzoraka izmeta $(\mathrm{n}=14)$ dobiveno je 40 izolata (leopard $\mathrm{n}=26$, antilopa $\mathrm{n}=14$ ) E. coli i 2 izolata $P$. aeruginosa (antilopa $\mathrm{n}=2$ ). Pronađeno je 11 izolata otpornih na karbapenem, od kojih je 10 E. coli i 1 P. aeruginosa. Određena je minimalna inhibicijska koncentracija (MIK) za meropenem za izolate otporne na karbapenem, od 8 za E. coli i $64 \mu \mathrm{g} / \mathrm{mL}$ za $P$. aeruginosa. Svi izolati E. coli i $P$. aeruginosa fenotipski su bili otporni na širok spektar lijekova, a 6 izolata $E$. coli proizvodilo je betalaktamaze širokog spektra (ESBL). Genotipskim probirom 7 izolata $E$. coli i 1 izolat $P$. aeruginosa bili su pozitivni na karbapenemaza gen blaNDM. Otpornost na karbapenem putem efluks pumpe zabilježena je u 4 izolata E. coli $(36,4$ \%, 4/11). Od 6 ESBL producirajućih CRE, 4 izolata nosila su gen blaCTX-M-1. Izolati E. coli također su sadržavali blaTEM-1, blaAmpC, qnrA, qnrB, qnrS, tetA, tetB i sul1 gene otpornosti. Pretragom na šiga-toksin, Stx 1 i Stx 2 geni utvrđeni su u dva odnosno jednom izolatu. Tipiziranje plazmida CRE otkrilo je prisutnost blaNDM gena na Incl1 plazmidu. Multilokusno tipiziranje sekvencija plazmida (pMLST) izolata otkrilo je sekvenciju tipa (ST) 297. Pojava otpornosti bakterija na karbapenem u divljih životinja iz zatočeništva trebala bi biti javnozdravstveni prioritet.

Ključne riječi: ESBL; E. coli; šiga-toksin; divlje životinje; otpornost na karbapenem; NDM 